\title{
ERRATA
}

Revista Brasileira de Botânica / Vol. 26, fasc. 3

Pág. 217, $1^{\text {a }}$ coluna, último $\S$

- Linha 3: onde se lê "Euglena pyriformis", leia-se "Eugenia pyriformis"

- Linha 9: onde se lê "Euglena pyriformis", leia-se "Eugenia pyriformis"

Pág. $219,1^{\text {a }}$ coluna, $1^{\circ} \S$

- Eliminar $1^{a}$ linha: "Comparando-se os valores de sementes graúdas e"

Pág. 219, $2^{\text {a }}$ coluna, último parágrafo

- Acrescentar após a última linha outra linha com o texto: "migração de hormônios vegetais (Anjos \& Ferraz 1999)"

pág. 217:

\section{parágrafos corrigidos}

O surgimento de mais de uma plântula normal a partir de uma única semente poderia sugerir algum grau de poliembrionia em Eugenia pyriformis. Rizzini (1970) verificou que sementes de E. dysenterica têm substâncias inibidoras da germinação e que o potencial inibidor dessas substâncias aumenta quando o embrião começa a germinar e diminui quando há contato do inibidor com o ar. Se esse efeito ocorresse em Eugenia pyriformis, seria difícil a identificação de poliembrionia, pois um embrião poderia exercer inibição sobre outros. Os fracionamentos, nesse caso, poderiam estar anulando o efeito dos inibidores. A identificação de poliembrionia em E. pyriformis poderia ser prejudicada, também, caso as sementes | contenham embriões coalescidos, como observado em

pág. 219:

ᄂ - - - - - - - - - - - - -

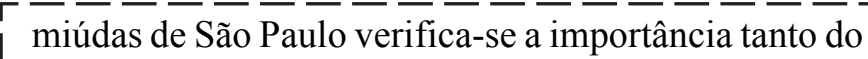
tamanho quanto da posição do fracionamento. As sementes graúdas que, no fracionamento transversal, tiveram FIG e FIP de 1,80 e 1,00, respectivamente, apresentaram 3,50 e 1,70 no fracionamento longitudinal (o que corresponderia a $350 \%$ de germinação e $170 \%$ de produção de plântulas normais). Contudo, considerando-se as sementes miúdas verifica-se que, embora o FIG tenha sido 2,50 (figura 12-A), o FIP foi 1,00 (figura 12-B), ou seja, não se obteve mais do que uma plântula normal por semente, portanto não apresentando vantagens em fracioná-las.

A elevada capacidade regenerativa das sementes de Eugenia pyriformis ficou evidente nos fracionamentos radiais, em quatro ou em oito partes. Em ambos os casos, para sementes de Mogi-Guaçu, obtiveram-se FIG e FIP nunca inferiores a, respectivamente, 1,50 e 0,90 (figura 12). Assim, fracionando-se a semente em até oito frações, ao menos uma das frações obtidas ainda pode produzir uma plântula normal. Nas sementes graúdas de São Paulo, os valores de FIG e FIP para sementes fracionadas em oito partes foram de 2,40 e 0,90 , respectivamente I (figura 12), ou seja, $30 \%$ das frações com $1 / 8$ da I semente apresentaram capacidade de germinar e aproximadamente $11 \%$ das frações obtidas puderam produzir plântula normal.

Os valores de FIG e FIP foram sempre superiores no fracionamento longitudinal, seguido pelo radial e, por último, o transversal (figura 12). Assim, fica evidente que o fracionamento transversal é o que mais prejudica a capacidade germinativa das sementes de Eugenia pyriformis.

Os resultados obtidos nos dois experimentos permitem inferir que, embora possível, é pouco provável que as sementes de Eugenia pyriformis sejam poliembriônicas como outras do gênero Eugenia (Johnson 1936, Gurgel \& Soubihe Sobrinho 1951, Lughadha \& Proença 1996) ou, ainda, que a obtenção de mais de uma plântula a partir dos fracionamentos seja oriunda de bifurcações da plúmula (Lughadha \& Proença 1996). A probabilidade de que os fracionamentos tivessem sido realizados, todos ou na sua grande maioria, na região de separação dos embriões ou na metade dos eixos embrionários é muito baixa. Reforça-se, portanto, a possibilidade de frações de sementes assumirem comportamento semelhante ao de estacas, com possibilidade de enraizamento e desenvolvimento de nova parte aérea, a partir da migração de hormônios vegetais (Anjos \& Ferraz 1999). 